Separation, Difference, and Time in Godard's "Ici et ailleurs" Author(s): John Drabinski

Source: SubStance, Vol. 37, No. 1, Issue 115: Cultural Theory after 9/11: Terror, Religion, Media (2008), pp. 148-158

Published by: The Johns Hopkins University Press

Stable URL: https://www.jstor.org/stable/25195161

Accessed: 17-05-2019 00:25 UTC

JSTOR is a not-for-profit service that helps scholars, researchers, and students discover, use, and build upon a wide range of content in a trusted digital archive. We use information technology and tools to increase productivity and facilitate new forms of scholarship. For more information about JSTOR, please contact support@jstor.org

Your use of the JSTOR archive indicates your acceptance of the Terms \& Conditions of Use, available at https://about.jstor.org/terms

The Johns Hopkins University Press is collaborating with JSTOR to digitize, preserve and extend access to SubStance 


\title{
Separation, Difference, and Time in Godard's Ici et ailleurs
}

\author{
John Drabinski
}

\begin{abstract}
"This revelation of distance is an ambiguous revelation, for time destroys..."
\end{abstract}

-Emmanuel Levinas

Is it possible to conceive a language of absolute difference? Or, is absolute difference always complicated by the identity-function of language? These questions have occupied French philosophy at least since Levinas's Totality and Infinity. In what follows, I renew the problem of heterology with attention to Jean-Luc Godard's film Ici et ailleurs, released in 1976. I will argue that Godard's treatment of space, space-time, and time-especially the latter, in the figure of the corpse-opens another modality of philosophical language, one sufficient to the task of articulating absolute difference.

\section{The Story of Difference}

At least since Heidegger, one could argue, continental philosophy has told a long story about difference. Vicissitudes of difference, to be sure, but always a story about difference. The primacy of identity gives way to difference, or perhaps difference is shown to have already put identity in question. Identity runs aground in the wake of a radical alterity - an alterity uprooting identity with a challenge from outside its borders. And the challenge is largely the same, whatever its manifestation: indigestibility in the tradition. The borders of the tradition are transgressed -perhaps before their establishment-by the indigestible, without promise or possibility of return.

Still, tradition dies hard and often comes to bear on even the most radical conceptions of difference, marking radical gestures with traces of conservatism. Derrida's critique of Levinas in "Violence and Metaphysics" is exemplary in this regard. Derrida's para-epistemological defense of Husserl's V. Cartesian Meditation remains conservative insofar as he maintains, against Levinas's magnum opus, the intractable character of identity. Let me raise the question again: is it possible to articulate difference without the recurrence of the logos? Or, further, does radical 
difference traffic, uncontaminated with identities, in the world's fractures, fissures, and myriad abyssal gaps? Central to my inquiry here is the question what is heterology?

For the Levinas of Totality and Infinity, difference is first the experience of separation. The Other who stands before me interrupts any pretension to a self-constituting identity, and this interruption is manifest in the economy of exteriority. The interval across and through which this economy labors is separation. Separation names a spatial and temporal difference prior to any identity, one always allergic to the various and suspect aromas of Sameness. Totality and Infinity is therefore dedicated to the intertwined tasks of deformalizing conceptual paradoxes (viz., the anteriority of the posterior), interrupting the reifications of transcendental philosophy, and, perhaps above all, to establishing the boundaries of a rhetoric adequate to the task of describing the quirky logic(s) of exteriority.

In this last task, Levinas no doubt finds himself halted by the bleakness of difference. Separation entails the loss of connection, loss of one's self and intimacy with others, and so separation initiates the experience of another kind of solitude even with the Other before me. It's no surprise, then, that there is always something mournful about Levinas's treatment of separation. The dominant figures of his conceptual schemas, and the rhetoric he deploys, bear witness to loss. What sense are we to make of this mournful undercurrent in his rhetorical strategy and its central figures? What does it mean that Levinas hails the priority of ethics, yet mourns over the first position of separation?

Why mourn at the precipice of separation? In other words, what is lost, and how does the ghost of that which is lost speak? Simply put, the first position of separation is preconditioned by the loss of the ego's security, and so registers across affects. While security-metaphysical or otherwise-is, for Levinas, the precondition of violence, the increasingly catastrophic language of how the I-as-refuge is severed from itself (going from interruption to trauma and persecution) testifies, in its own peculiar violence, to the necessity of loss as the ante-chamber of the ethical. The refuge masks the refugee-we are always already abandoned in and by this ante-chamber of the ethical. All the while, this antechamber is itself prior to what it interrupts-ante of the ante. Loss is doubled in just this disorientation, and so is maintained as loss in the rather dizzy and dizzying anxiety of responsible subjectivity. Vertigo become ethics, doubled in loss, transforms the I-as-refuge into the Meas-refugee whose separation is saturated with anxiety. 
If anxiety, as Freud claims, arises when one loses mastery of one's self, then the conceptual terms of a Levinasian anxiety are obvious. Separation and diachronic time stall mastery at its origin by fracturing identity before identity takes root. The posteriority of the anterior. This anxiety about separation is not without antidote, and in that antidote lives the ghost of what is lost, then mourned, in separation-a ghost in the guise of a mournful need for reparation. Mourning repairs what was perhaps first irreparable in melancholy, and in the Levinasian register is tantamount to suturing the wound of diachronic time. Indeed, Levinas vitiates difference in two conceptual moments: contact and the messianic. The present (contact) and the future (messianic) contaminate the purity of loss. The past is thereby redeemed in a two-fold reverence: he who stands before me, and the utopic posture in relation to the to-come.

What would it mean, however, to engage separation without antidote or vitiation? What if loss maintains an "abyssal-between" in separation-obliterating the interval-thereby returning mourning to melancholia? That is, what would it mean to have lost not only contact in separation, but to have also lost the right to mourn loss of contact? Difference without the mournful promise-hope, even-of the messianic? In other words, what if the wound of diachrony remained just that-a wound estranged from even provisional healing treatments? In the present inquiry, I take that estrangement seriously, as a response to my leading question: what is heterology?

\section{Godard's Ici et ailleurs}

In what follows, I want to examine Jean-Luc Godard's enigmatic Ici et ailleurs, his film about a Palestinian uprising, released in 1976. This film, like so many in Godard's oeuvre, is less a film about philosophy than a mode of philosophical discourse itself. Therefore I would add to my leading question: what does Godard offer to the problem of thinking heterology without the recurrence of the logos? Is there an anxious, melancholic difference in Ici et ailleurs? And how might cinematic language-so often an anti- and ante-language in Godard's hands - think heterology?

Ici et ailleurs is a peculiar film. At first glance it appears to be nothing more than a fragmented documentary about the Palestinian uprising in 1970, mediated via a typically Godardian commentary on televisual transmission, and a short meditation on the meaning of filmmaking. These fragments are threaded together with the political and moral question of revolution's failure. But these explicit features of the film function less as thematic master stories than as Leitfaden. So, to what are documentary, transmission, and failure leading clues? 
I would like to propose an answer rooted in two claims about Godard's film. The film's title, always our first frame, is everything. It names not the theme, but the function of the cinematic language to follow. Image and sound, the film is itself "here and elsewhere." That is, the film is concerned with two competing issues clustered around its title: the here and elsewhere of the image and the here and elsewhere of a representation haunted by, yet never responsive to, death.

First issue: Godard's attention to the fate of the image places Ici et ailleurs squarely in the dominant, even obsessive filmmaking motifs of his collaborations with Anne-Marie Miéville, as well as in the shadow of Guy Debord's book, Society of the Spectacle, published less than a decade previously. The film is concerned with spatiality as both an origin and a modality of transmission; transmission therefore entails the spatialization of the time between destinations. The here and elsewhere/ici et ailleurs of the image configures relation spatially (via the and/et); these terms are locative insofar as the difference is fundamentally geographicwritten in and across space.

Second issue: the problem of representation and death. Here, death changes everything and radically undermines the first issue: transmission. Death undermines the spatial image by dislocating not geographic location, but geo-graphy itself. There is no locative writing without a geos across which to measure both separation and transmission. Death's disturbance of time enacts, for Godard, a separation traversed only by ghosts. Yet, this is a film; there must be representation, so the question is how Godard might represent the ghostly. The ghost of Ici et ailleurs is carried by the abyssal "image" of the burned Palestinian corpse. This image, mute and without reticence, is first temporal, and its capacity to bear its own catastrophic sense decides the film's success or failure. At the moment of the film's success, when the image of the burned corpse becomes the anti- and ante-image, time itself comes to destroy the film. This mute and ghostly time of the corpse tears spatiality and the image asunder with a loss initiated by death's irreversible absence. Indeed, Godard's oblique, yet decisive engagement with time changes everything about the here and elsewhere of the film, in an act of de-location. What remains is a different kind of separation, a separation without contact or future, and thus a pure memory of loss as loss, without the mediation of anxiety. The here and elsewhere of death's haunting configures relation temporally; these terms are a-locative, traversed only by ghostly disturbances. Ici et ailleurs becomes, at that moment, an anxious, melancholic film without redemptive effect or affect. 
And so Ici et ailleurs is as much about the act of filming - the fate of a certain kind of representation, under certain conditions, spatial and temporal-as it is about the political events documented. The act of filmmaking is fractured by the unsaid image and death. In death, Godard's cinematic language is fractured by an unsutured abyss of separation. Thus, that language both encounters and sustains the interruption of an unmediated difference. The intractable character of heterology in the ubiquity of loss, folds the film back into itself. Split by the term of relation -the et of Ici et ailleurs - there is no "there" in which the film can take root.

\section{Here and Elsewhere}

Again, the first frame, the title, means everything: here and elsewhere, not here and there. Godard is faced with the impossible aesthetic paradox of making a film "on location" without location. This is where the film's narrative speaks, but also only rambles into incoherence. Ici et ailleurs, as cinematic language, is therefore a kind of discourse about separation and difference without contact-locative discourse which, in the interruption of space by time, in the ghostly traversal borne by the corpse, becomes an a-locative separation. What does this mean for the meaning of difference? What kind of story does Godard tell with this difference?

Once more, the title. What does it mean that Godard gives his film the title Ici et ailleurs? First, of course, the title underscores the separation and difference, a difference at the center of the film separated by an ambivalent conjunction. But what sort of separation and difference? My ultimate claim is that the meaning of the distance between ici and ailleurs is diachronic. But this raises a question: is the film not about topological separation? There are four distinct instantiations of "here" and "elsewhere," each further subdivided throughout the film: France/ Palestine, Spectator/Actor, utopia/defeat, and the division of the film within itself as documentary/failed-documentary. Each disjunct moves across space, from a "here" to a "there"; the long series of disjuncts in sound and image begins as the film shifts location from Palestine to France-quite literally, in the opening motif, tracing the title as a fissured image (and so not a conventional, proper name) from focus (ici) to out-offocus (et) to another focus (ailleurs). And this is no doubt part of Godard's explicit anxiety in the film. The narrative thread, to the extent that one exists, consists of the instability of the film's two locations. The footage (actor) is Palestine, the film (spectator) is France. At this level, Godard's strategy is explicitly didactic; the locative terms of separation are 
unambiguously-though not without ambivalence-confirmed in the repetition of two sites, two bodies, two voices-in a word, two geographies. This tells us the "here" and the "elsewhere," but not yet the "and"-the relation of the out-of-focus. Conjunction's out-of-focus character destabilizes the two terms of relation.

Thus, the two geographies, whether they be political or psychological, sit divided by an abyss. The $e t$ is out-of-focus, yet relates. Why the abyss? To what end is Godard obsessed with an abyssal separation? This returns us to the question of the story: whence and whither. A sense of the direction of Godard's story forms a sort of halo around the question of abyss - indeed, this is a halo produced by the abyss itself. The story, it turns out, is a moral tale. As Godard says in a voice-over:

Probably we don't know how to see or to listen. Or the sound is too loud and drowns the reality. To learn to see in order to hear elsewhere (ailleurs). To learn to hear oneself speaking in order to see what the others are doing. The others, the elsewhere of our here. ${ }^{1}$

Godard's confrontation of the image aims at the collapse of at least a bit of the separation carried by the et of Ici et ailleurs. And with good reason. Godard is well aware of the problem of a separation in which the only contact with the Other is the image of the Other. That is, the cognitive economy of the image makes what is other become immanent. The cinematic image is a particularly striking example (to the point of excessive violence) of this economy. Images relate, and so betray. Cinema's trickery consists in concealing betrayal in the facilitation of identification and in arousing sympathy. In another voice-over, Godard refuses this trickery:

Poor revolutionary fool. Millionaire in images of revolution.

Poor revolutionary fool. Millionaire in images of revolution.

Poor revolutionary fool. Millionaire in images of revolution.

Thrice repeated, with good reason. Godard's famous strategy of unbending didacticism, here on rather crude display, awakens the viewer to both the cinematic process of information transmission (reminder: you are seeing images of the dead) and repetition as the labor of imageproduction. Thus, the thrice repeated phrase is said/written/represented with no shortage of irony; there is a reproduction of the image of the revolutionary viewer at the very moment the viewer becomes aware of the distance between the image and the elsewhere of that image-the Palestinian revolutionary in the field with maps, guns, and too much death. There is this image, which incites our identification and all attendant affects. There is also the corpse whose ghost haunts not just its 
own ruined image, but also the image of the living. In other words, there is always disturbance in identification - an anti- and ante-image. And so there is Godard's persistent question in Ici et ailleurs, a question asked in sound and image: "Where is the agreement or disagreement of the Other (l'autrui)?" How can the Other accuse? Godard's voice-over tells us:

The story, it turns out, is a moral tale. The Other must be able to speak agreement or disagreement. The Other must be able to disturb the image.

And therein lies the filmmaker's originary separation, a separation made only more disastrous by the moral tale. The image does notindeed cannot-carry itself. Rather, it is staged, managed in montage, or simply discarded on the editor's floor. The space and time of the image refer to the space and time of the image; the film's logos appears to be selfcontained. As Godard puts it in an important voice-over:

And the film that is, on the whole, a chain-work of image renders a "good" account, through this series of images, of my double identity, space and time chained one to the other as two workers on the assembly line, where each at the same time is the copy and the original of the other.

The documentary image complicates this image-copy-original sequence further with the documentary's more crucial component: memory. A documentary has responsibilities to the Other that are not due in fiction. Because the Palestinian uprising fails before the film is actually produced ("We had wanted to crow about victory," Godard says in the film's final moments), the film, as a documentary and with all its attendant responsibilities, is necessarily conceived and executed as an act of memory across a separation. Godard remembers something in image and sound; there is documentation, whatever the disassembly of the image. Yet, as memory, the cinematic image fails its origins at the moment it becomes image. The production of memory as image means subjection to the logic and labor of the assembly line: a "chain of images," "arranging memories," "chaining them in a certain order," all so that the elsewhere-in its cinematic, virtual parousia-becomes here as one "rediscovers one's own image." The filmmaker himself is the first betrayal of elsewhere; the spectator cannot but fall under the image's seduction. Seduction's pleasures obscure the Other's agreement or disagreement. Indeed, my pleasure in the image responds to the fetishistic character of the Other as image. For Godard, however, this is not only (or even primarily) a problem of identification with the victim. Rather, it is a problem of the persistence of narcissism in the transmission of the image. The spectator is seduced by the image itself into seeing only him or herself 
in the image. Perhaps that is always the economy of identification. Whatever the pretensions of sympathy and its overly earnest sibling, empathy, perhaps we see only ourselves in the Other.

"Elsewhere," then, comes to name that Other who speaks or lies mute, of its own accord. The filmmaker is a trafficker in space, so the image fails. But it is a fecund failure if it produces separation. Failure, then, opens up and opens our fractured vision to an abyssal separation of location. Here and elsewhere, refusal of the image, transmission of memory, the moral tale - all of these differences and imperatives originate in a separation of location. The heterology of Ici et ailleurs is an essentially locative sense of difference.

A decisive moment of hesitation: is Godard's "elsewhere" always a locative term? Does the limitation of the image derive from irreducible spatial fractures? Or, further (even before), does the fecundity of this failure also de-locate?

\section{The Ghostly Language of Temporal Separation}

The locative term, in separation and difference, must move across space and a spatialized time. The crisis of the image is the staggered movement across both space (spectator/actor, France/Palestine) and spatialized time (time of the act/time of the filmmaker-a distinction that temporalizes spectator/actor, France/Palestine). But, is Ici et ailleurs entirely concerned with space, geography, and therefore with topologies of difference, distance, and separation? Again, Ici et ailleurs labors against the image. But there is also the corpse, repeated as burned and mute. How might the burnt and faceless flesh labor against the image otherwise than via limits of space and location? In the corpse's refusal to performmute and without face-Godard transforms separation from a laboring against into a laboring for. That is, with this anti-and ante-image, the film labors as well for the ghosts of both that image and the labor deployed against it. These ghosts, haunting across separation in/as time, invoke a language of temporal separation. The corpse is just that enigmatic presence; it bears time, or at least should bear time. The corpse commands image as time, without space, so that the abyssal separation of death registers its fissure. That command comes from the corpse as a radical other, an alterity without alter ego. Is Godard capable of making a film about temporal separation, and so a film responsive to this command?

Now, while spatiality is implied by the title-a topos rather than chronos - the outset of the film confirms that between here and elsewhere is also-perhaps first of all-time. Before the corpse interrupts Godard's 
story against the spatial image, Godard has already built time into the film. He says:

Space has inscribed itself on film in another form, which is not a whole anymore, but a sum of translations, a sum of feelings which are forwarded - that is, time.

Transmission, then, is always about time. On first glance, that is a rather mundane claim, until one ponders that transmission without location-i.e., until the burnt and faceless corpse interrupts with its muteness. Faceless and without location, the corpse bears another sort of time, a time without spatialization, and so a time that interrupts with its marking of heterology. Pure heterology?

\section{A Failure of Time}

If Ici et ailleurs enacts separation in failure, then the interruption of space by time must take place in a temporal failure. Godard is explicit on this, as the film begins with a slippage of dates. Thus the film begins with a failure of time, centered around the problem of death - a failure that fractures the film and opens space for the mute disturbance of death's time. The film opens with two dates: 1970 and 1974. These markers are not simply icons of sequential time; rather, they are uttered as the indigestible chiasm of the Palestinian refugee: victory crossing death. That is, the dates indicate a stretch of failure: 1970 begins the promise, 1974 marks the defeat. Godard begins the film:

In 1974, it is called "Here and Elsewhere," and elsewhere, and...In 1970, this film was called "Victory." In 1974, it is called "Here and Elsewhere," and elsewhere, and...

The dates also refer to this: "All of the actors in this film are dead." Death, defeat, and loss render the two dates a disjunctive fracture; 1970 is the time of life, 1974 is the time of death. And there is no reconciliation of the two. The corpse is unredeemed in its facelessness, neither martyr nor victim. Only loss. Such is the effect of the ubiquity of death in Ici et ailleurs. But these opening dates are not the whole story. Godard changes the dates. The outset of the film sets the time-disjunct as 1970/1974, but the close of the film posts a decisive shift in dates: 1970/1975.

Why this shift? What does it signify about the film? Godard reminds us at the close, of the diachronic structure of the film we have just seen. We could not see or hear the first disjunct (1970/1974), despite its announcement, but could only hear upon registering the last disjunct (1970/1975). The closing disjunct, 1970/1975 marks the time of production. This is what we see and hear in the quasi-narrative and its fractures. As such, the closing disjunct is largely the time of the filmmaker, the time of the image 
and space, and so also the time of France, of the spectator, of the documentary, and of the possibility of utopia. To this time is always bound space. So, it is always an interrupted interruption, a compromised or impure heterology. Yet, the closing disjunct is always already displaced by the opening disjunct of 1970/1974; the time of the film becomes two times, or at least we are reminded of the two times always already having been functioning. The announcement of 1974 marks death and loss as such, before production and image-space, and so it is the time of Palestine, of the actor, of the failed documentary, and of defeat. In other words, the time of the corpse. "All the actors in this film are dead," Godard remarks, which means that one time of the film-time as such, betrayed in the image - is already dead. The difference of this dead-time is absolute.

And so we close with the corpse. The corpse, burned and Palestinian in Ici et ailleurs, is a radical figure and image. As a figure, the corpse bears death's weight in an abyssal absence. Because the corpse cannot speak, there is no presence in the transmission of sense. There is only the failure of presence and sense: an irredeemably fractured transmission. As an image, then, the corpse is an interval into the abyss; its silence, burned and unidentifiable, defeats the economy of image-production with what is against and before the image: death.

The corpse is 1974, the time of death. The fighter is 1975, the time of the living. So is the violence of cinema itself, insofar as cinema carries with it always the possibility of resuscitation-making the corpse alive again in the image of the fighter, a redemptive resuscitation. The image stalls the negative dialectical work of death, but in Godard's hands, the slippage of dates and the mute obstinacy of the corpse maintain the power of the indigestible. Holding the two in place-locative and alocative, space and time, life of loss and death of loss-Godard is able to expose an absolute difference, not as an interruption of identity, but as that which has always already structured our encounter with loss. Our encounter is with the life of loss, the image of loss that, while complicated, nevertheless mourns and sutures the wound of separation. But that encounter is always late to the scene. The mute corpse, the abyssal image, de-locates separation - a separation of difference without space, only time. It is this time without space that fore-structures space and the temporal interruption of space in the image of death. It is the time of death itself, exposed in the failure of space to bear time. That is, the time of the corpse against its own image, the out-of-focus "and" of relation. Time disturbs space; so too then does it disturb Godard's literal and figurative lens. 


\section{Conclusion}

Let me conclude where I perhaps should have begun. For those of us concerned with the problem of difference, there is no more forceful enigma than that of language. Derrida's work not only reminds us of this enigma, but grounds us at the very moment we might seek to unground an articulation of difference. And this is so much more the case with the problem of absolute difference. Moved by Derrida's critique in "Violence and Metaphysics," Levinas in his later work appeals to an "abuse of language." The poetic-we could take Celan's work as exemplary-is certainly a site of abuse. But we who want to defend, or at least explore, a pure heterology would do well to consider the possibilities of cinematic language. Cinematic language is the play of presence, of course, to the extent that it is always and intractably about sounds and images. This is why Godard's work is so important. Godard's cinema is always a philosophical language against presence, coincidence, dialectics, and any coherence of representation. Sound and image work and fail to work in important ways, and in that sense become a philosophical language abused by staggered movements and non-movements of parousia. For Godard, the work of image-production always effects a phasing and dephasing, where time itself interrupts the sequential character of imageplay. It is precisely in that phasing and interruption of sequentiality that a language of heterology becomes a possibility rather than a paradox.

Hampshire College

Note

1. All quotations are from the Facets Multimedia release of Here and Elsewhere, with only minor alterations in translation.

\section{References}

Derrida, Jacques. "Violence and Metaphysics: An Essay on the Thought of Emmanuel Levinas," in Writing and Difference, trans. and ed. Alan Bass. Chicago: UCP, 1978.

Levinas, Emmanuel. Totality and Infinity: An Essay on Exteriority. Trans. Alphonso Lingis. Pittsburgh: Duquesne University Press, 1969. 